\title{
テラヘルツ波による塗膜下腐食検出と複雑光応用の可能性
}

\author{
布施則一 \\ 電力中央研究所 ( T240-0196 神奈川県横須賀市長坂2-6-1)
}

\section{Corrosion Detection Using Terahertz Waves and Availability of Laser Chaos Application}

\author{
Norikazu FUSE \\ Central Research Institute of Electric Power Industry, 2-6-1 Nagasaka, Yokosuka, Kanagawa 240-0196
}

(Received November 18, 2016)

\begin{abstract}
The applicability of terahertz waves to the detection of rust under coatings is discussed, focusing on the electromagnetic waves generated from chaotic multimode semiconductor laser oscillations. The corrosion states of steel used for the cross-arms of electric transmission lines are provided as maps with a special resolution down to the sub-mm level to reveal transfusion of rust fluid. These analyses are made possible by the chemical structure of rust, which shows an absorption band tail in the terahertz frequency region. Terahertz waves generated by the optical excitation of photoconductive antennas using a chaotic laser show that the absorption band tail extends to around $180 \mathrm{GHz}$. Chaotic laser systems using small and inexpensive semiconductor lasers are potentially promising tools for detecting underfilm corrosion.
\end{abstract}

Key Words: Underfilm corrosion, Terahertz waves, Spectral analysis, Surface scattering, Chaotic oscillation

\section{1.はじめに}

送・変電設備では, 構造材やタンク容器材として鋼材 が広く用いられる。これら鋼材には，防食を目的に亜鉛 めっきや塗装が表面に施されている。しかし, 経年とと もに塗装に亀裂などが入り，塗膜下腐食が誘発される。 そのため, 屋外電力設備の鋼材発錆は高経年化対策課題

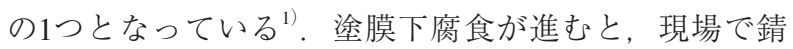
を取り除くケレンの難易度が高まり，費用と時間がかか る.また，鋼材と防食塗膜の接着性といった品質確保も 難しくなる，そのため, 一般的には, 塗膜劣化が進行す る前の塗替えが推奨される。

ただし，高経年設備の増大や，コスト削減等の影響 で，塗替え等の工事は従来のようには進んでいない。こ れは, 点検等により対策の優先度を決定し, 工事量を平 準化することが求められていることを意味する。塗膜下 腐食では, 評価領域の塗膜性能が良好でも, 錆汁等の塗 膜下での染み込みなど，近隣の腐食状態の影響を受ける 可能性がある。このような塗膜下での発錆とその進展に 関する知見は, 効率的な補修作業計画の立案や鋼材の寿 命延伸に貢献できると期待される。このための2次元的 な腐食検出には, 電磁波の適用が有効である.

各種金属酸化物は, その化学構造由来の固有吸収スぺ クトルをテラヘルツ $(\mathrm{THz})$ 帯に有することから, $\mathrm{THz}$ 波 により塗膜下の腐食を検出することができる ${ }^{2-6)}$ 。本稿
では，筆者らの取り組み ${ }^{7-11)} の 一$ 部を紹介したのち，ス ペクトル解析および計測技術の観点から腐食の検出に適 する電磁波の周波数帯について議論する。また，実際の 計測に際しては, 光源の安定性, システムの低価格化, 狭い空間の評価ができるような小型プローブが必要とな る。これらを解決する可能性の1つとして，レーザーカ オスにより発生されるTHz波の利用について議論する.

\section{THz波による塗膜下腐食の検出}

2.1 鉄塔廃材に対する $\mathrm{THz}$ イメージング

太平洋沿岸の送電鉄塔で架空地線腕金に用いられたL 字アングル鋼 (長さ $74 \mathrm{~cm}$ ) に対しTHz波を照射し，その 反射強度分布 $\left(\mathrm{THz}\right.$ イメージ)を測定した ${ }^{10)}$ 。ここでは, Advanced Photonics製T-ray 4000 12 を用い, フェムト秒 レーザー励起による時間幅約 $0.8 \mathrm{ps}$ の $\mathrm{THz}$ パルス波を光 源に, $0.5 \mathrm{~mm}$ ピッチで時間領域分光法により各点での 反射波形を取得した。分析部材の外観をFig. 1 (a)に示 す。海風を受ける面において塗膜が消失している一方, 他の面では塗膜が残存する。すなわち，面方位により環 境因子の寄与度が異なる。

よく知られるように，防食塗膜に用いられるエポキシ 樹脂などの有機高分子はTHz波に対し良好な透過性を示 す。その一方，THz波は鉄錆には強く吸収される。した がって，イメージング測定において，反射THz波が減衰 
している領域には腐食生成物が存在すると推定できる。 結果を示すFig. 1(b)によれば, 塗膜残存面でも腐食面と 同程度にTHz波反射が弱いことが分かった。これによ り，塗膜残存部にも腐食が侵入している可能性が示唆さ れる。一方，試料上部の塗装面では，他部材が海風を 遮ったためTHz波反射が強い。そのため, 海塩付着の差 異が腐食進展に大きな影響を与えていると考えられる。 なお，試料上下に存在するボルト穴付近では亜鉛が露出 している。ここが塗装施工されなかったのは，供用時に 他部材と接合していたためと推定される。この接合部で は反射が強く, 腐食因子の浸入が少なかったことが示唆 される。

Fig. 1(b)の黒実線に沿って測定したTHz波反射時間波 形をFig. 2 に示す。第1波は各地点での表面反射波に由 来し, その反射振幅は塗膜, 鉄錆あるいは亜鉛めっきの 屈折率 $n$ にり決定される。これに続く第 2 , 第3波との 時間差から, 塗膜と腐食の膜厚はそれぞれ $170,110 \mu \mathrm{m}$ と求まり, この值は電磁膜厚計による計測值と概ね一致 した.

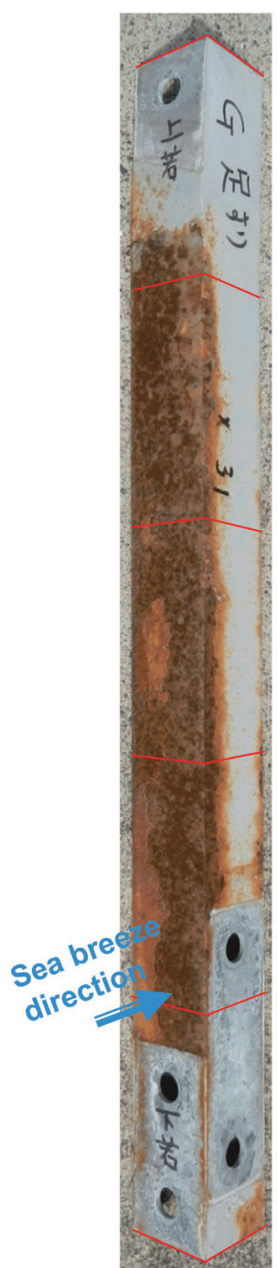

(a)

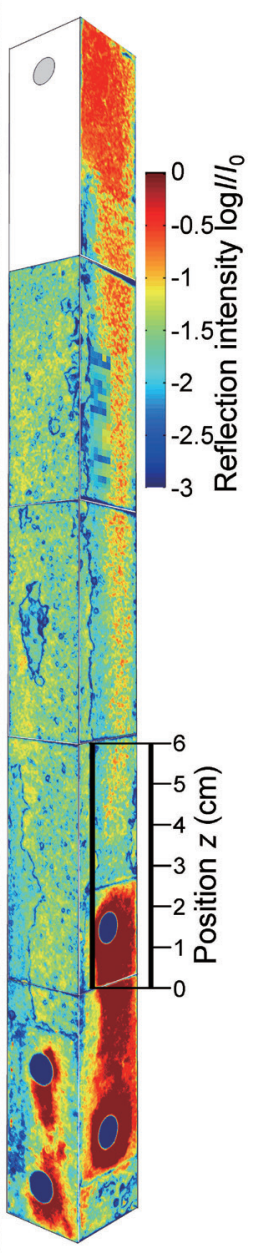

(b)
Fig. 1 Appearance (a) and THz reflection intensity distribution (b). ${ }^{10)}$ The sample was cut along the red lines shown in (a), which resulted in weak $\mathrm{THz}$ reflection at these lines. $I$ and $I_{0}$ at the color-bar caption in (b) are the incident and reflected intensities of $\mathrm{THz}$ waves, respectively.

\section{2 腐食検出に適する周波数領域の検討}

セラミック光源を利用したフーリエ変換 $\mathrm{THz}$ 周波数帯 分光光度計 $(\mathrm{JASCO}, \mathrm{VIR}-\mathrm{F})^{13)}$ を用い, この波数帯にお ける種々の鉄錆の吸収スペクトルを計測した。結果を Fig. 3 に示す7)。黑錆として知られる $\mathrm{Fe}_{3} \mathrm{O}_{4}$ は $350 \mathrm{~cm}^{-1}$ と $570 \mathrm{~cm}^{-1}$ に特徵的な吸収バンドを示す。一方, 赤錆であ る $\gamma-\mathrm{FeO}(\mathrm{OH})$ は220，270，360，470 $\mathrm{cm}^{-1}$ に吸収バンドを 示す。これらスペクトルはポリエチレン粉末中に高純度 の錆粉末を数\%添加したペレットに対し，透過光学系に より測定した。計算された吸光度が3を超えるものもあ るなど，この試料により THz波が数桁減少する事実は, 鉄錆によるTHz波吸収が非常に強いことを示唆してい る. Fig. 2 の撤去部材からのTHzパルス波の反射におい て，第3波は腐食層最深部からの反射である。 $z=2.8$, $4.4 \mathrm{~cm}$ での波形では, これが現れる時間が遅く, この地 点での腐食層が厚いことが示唆される，実際，このとき の第3波の振幅は弱く，腐食層による $\mathrm{THz}$ 波吸収も大き いことが分かる。

Fig. 1，2の測定に用いたTHzパルス波の中心周波数体

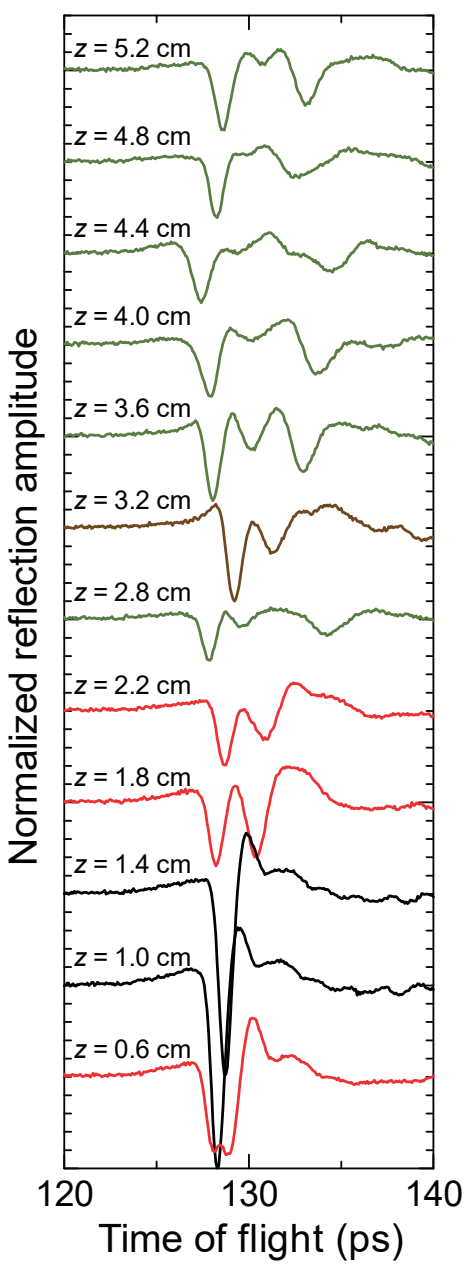

Fig. 2 Time-of-flight amplitude spectra of reflected THz wave collected along the "Position $z$ " shown in Fig. 1(b). Colors in green, brown, and red represent spectra obtained at a surface with its coating intact, at a rusted surface, and at a $\mathrm{ZnO}$-coated surface, respectively. The amplitude is normalized by the incident $\mathrm{THz}$ waves. 


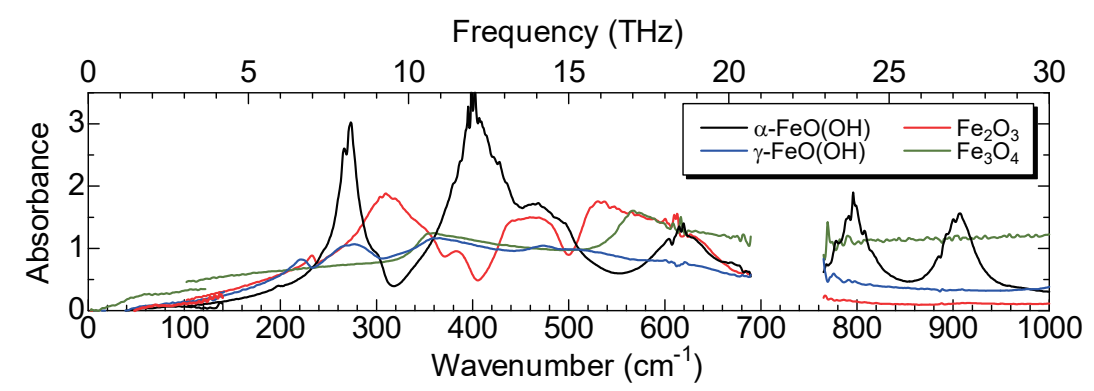

Fig. 3 Absorption spectra of several iron molds in powder form observed using THz-TDS and FT-THz system with the transmission method. ${ }^{7}$

は概ね0.7 THz付近にある。したがって，得られたイ メージング結果は鉄錆の吸収バンドの裾による吸収を利 用したものである。この状況でも, 腐食層が厚い場合に は反射THz波は激しく減衰する場合がある。そのため, 腐食が激しく, 長い探査深度が求められる部材において は, さらに周波数の低いTHz波の利用が求められると考 えられる。

ところで，塗膜下に腐食が生じる場合，部材表面には 凹凸が発生し，これがTHz波の散乱要因になる。実効反 射率 $R$ は凹凸面各点からの反射波の位相差の合成で得ら れる，表面変位分布が正規分布に従うと仮定できると き, $r m s$ 表面粗さ $\delta$ の影響はDebye-Waller因子として知ら れる次式で表される14).

$$
R=R_{\mathrm{s}} \cdot \exp \left[-(4 \pi \delta f / c)^{2}\right]
$$

そのため，高い周波数成分を持つTHz波では，腐食によ る吸収以外にこの散乱による減衰についても考慮する必 要がある。上式の対数より, 実行反射率の自然対数であ る $\ln R$ を $f^{2}$ に対してプロットすると，傾きが- $(4 \pi \delta / \mathrm{c})^{2}$ と なる。詳細は既報 ${ }^{11)} に$ に譲るが，Fig. 2 の計測を行った領 域において，表面反射波を対象に上記 $\ln R-f^{2}$ 解析を行い， $\delta$ 評価を行った。一例としてFig. 2 の $=3.6 \mathrm{~cm}$ で得た波 形に対する解析結果をFig. 4 に示す。 ここでの傾きは$0.53 \mathrm{THz}^{2}$ となり， $\delta$ は約 $17 \mu \mathrm{m}$ となった。なお，このス ペクトル解析に際しては, 解析対象である表面からの反 射波のみを抽出して行った。測定面全体での解析の結 果, 裏面に腐食が存在すると推定される領域において, 塗膜表面の $\delta$ は概ね $20 \mu \mathrm{m}$ と推定された。式(1)によれ ば, $1.5 \mathrm{THz}$ 電磁波はその $80 \%$ が散乱される。一方, 照射電磁波の周波数が $0.3 \mathrm{THz}$ ま゙低ければ, 表面散乱 による減衰は6\%程度に留まる。低周波THz波が表面形 状の影響を受けにくいことは, (1)腐食層の奥まで探査が

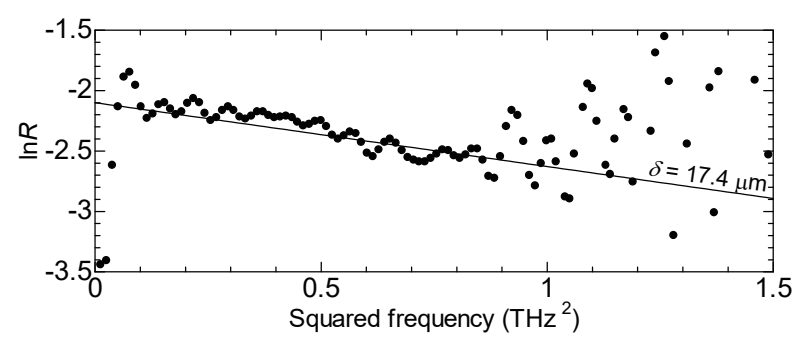

Fig. 4 Plot of $\ln R$ vs. $f^{2}$, analyzed for the waveform obtained at position $z=3.6 \mathrm{~cm}$ in Fig. 2 .
見达まれるとともに，(2)得られる反射強度分布は散乱影 響の補正をせず，直読でも腐食状況を示すことになる。

\section{3.レーザーカオスより発生されるTHz波の可能性}

鉄錆によるカオス光励起THz波の減衰度合いを評価す ベく, Fig. 5 の光学系 ${ }^{15,16)}$ を利用した。半導体レーザー からの出力光は, ビームスプリッタ $\mathrm{BS}_{1}$ とその先にある 外部鏡で戻され，この光学的遅延帰還によりカオス発振 がなされる。半導体レーザーは廉価で小型であるが，そ のまま光伝導アンテナ $(\mathrm{PCA})$ に入射する場合, 発生する $\mathrm{THz}$ 波は帯域が狭く，安定性に問題がある。一方，励起 光源をカオス光にすると, $\mathrm{THz}$ 波の帯域および線幅が拡 大され, また, 安定化する. カオス光は短時間ではモー ドホップが激しく発生し, 光スペクトルは安定しない. しかし，多モード化することで，いずれかのモード間で 光ビートが発生するため, 時間平均のスペクトルは安定 することになる ${ }^{16,17)}$.

$\mathrm{THz}$ 波発生側のPCA (ギャップ幅5 $\mu \mathrm{m}$ のダイポールア ンテナ)にはロックイン検出のための交流電圧 $(40 \mathrm{kHz}$, $\left.100 \mathrm{~V}_{\mathrm{p}-\mathrm{p}}\right)$ が加えられ, 励起光の縦モード間のビートによ る摇らぎによって, THz波が発生する。一方, 検出側で は可動レールによりレーザー光のTHz波に対する時間遅 延を変化させ，PCA上で両者の相互相関を取る，検出信

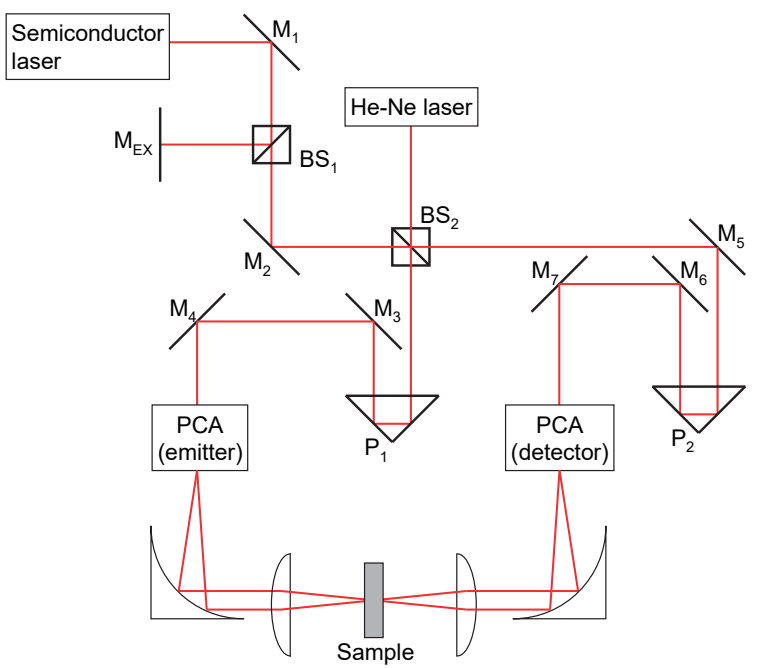

Fig. 5 Experimental setup for THz generation and detection using laser chaos. M, BS, and P stand for mirror, beam splitter, and prism, respectively. ${ }^{15,16)}$ 
号はロックインアンプ（時定数 $300 \mathrm{~ms}$ )を通し，電流と して取り出される。本章では, このsub-THz波の錆粉末

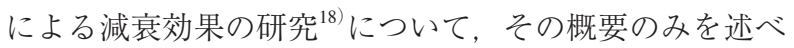
る.

光路長1 $\mathrm{mm}$ のパイレックスガラスセルに $\mathrm{Fe}_{3} \mathrm{O}_{4}$ 粉末を 充填し, THz波の減衰を評価した(Fig. 6). $\mathrm{BS}_{2}$ で分割し た後の検出用光伝導アンテナまでの $2 つ の$ 経路の距離が 一致したとき，その相互相関が最大となる，今回は，時 間遅延 215 psあたりでTHz波出力が最大となった。 セルに 粉末を充填したとき, 波形は 3.7 ps程度遅れて観測され た。このときのTHz波は, 特に210-300 ps，420-460 psの 間で減衰している。この時間波形のフーリエ変換によ り, 光強度の周波数スペクトルを得た (Fig. 7). 半導体 レーザーの縦モード間隔が47.5 GHzであり，主たる $\mathrm{THz}$ 波出力も, この間隔で発生している.ノイズレベルと比 較すると, 縦モード間隔の6倍の0.28 THz 付近までの発 生が検出できる。腐食粉末によるTHz波減衰は，4倍波 以降にて認められる。 このことは, Fig. 3 に示される $\mathrm{Fe}_{3} \mathrm{O}_{4}$ の吸収バンドの裾が概ね $180 \mathrm{GHz}$ 付近まで広がって いることを示唆している.

電磁波を用いた塗膜下腐食検出は, $70 \mathrm{GHz}$ 帯のミリ 波の利用から検討されてきた ${ }^{17)}$ 。このような低周波電磁 波は, Fig. 7 からも理解されるように腐食に対する感度 が弱い。 その結果, より高周波数側のTHz波に検討が 移っていった，たた，前章の議論のように，高周波数 $\mathrm{THz}$ 波は腐食生成物に強く吸収される上，表面散乱の影 響も受けやすい。レーザーカオスを用いたTHz波は，そ の中間の周波数帯の出力を有する. Fig. 6, 7で確認され た $\mathrm{Fe}_{3} \mathrm{O}_{4}$ による $\mathrm{THz}$ 波の減衰は, この電磁波が腐食検出 に利用できることを示している。ここで減衰が確認され

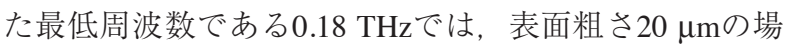

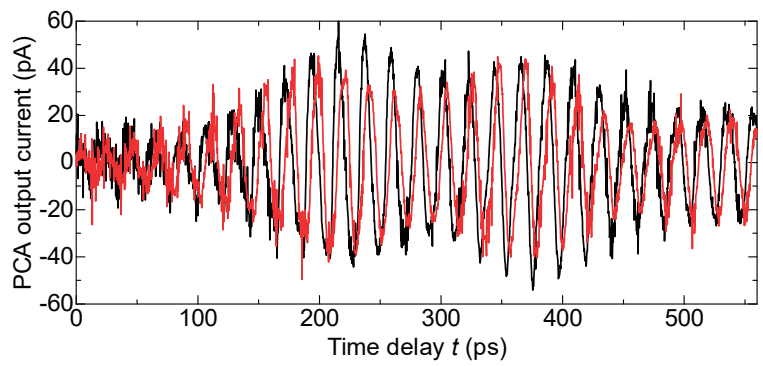

Fig. 6 Time series of $\mathrm{THz}$ wave. Waveforms in black and red were obtained by filling air and $\mathrm{Fe}_{3} \mathrm{O}_{4}$ powder in the sample cell, respectively. ${ }^{18)}$

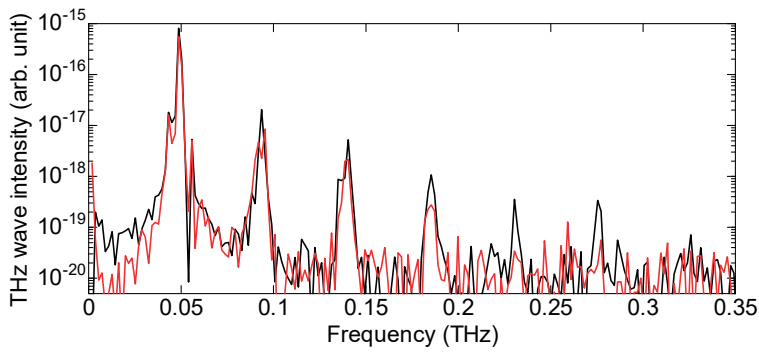

Fig. 7 Intensity spectra of $\mathrm{THz}$ wave. Notations for curves are given in the caption of Fig. $6 .{ }^{18)}$
合の減衰は2\%程度であり，殆ど無視できる，安定出力 が見込まれるレーザーカオス発生THz波は，励起光源が 廉価であることなどの点も含め, 塗膜下腐食検出システ ムの要素技術として期待できる.

\section{4. 結 び}

電磁波による塗膜下腐食評価としての，レーザーカオ ス $\mathrm{THz}$ 波の適用可能性について検討した。以下に得られ た知見をまとめる。

・フェムト秒レーザー励起によるTHz-TDSシステムを用

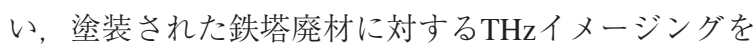
行った。 その結果, THz波は様々な塗膜下腐食様相を 明らかにする有効な分析手法であることが明らかと なった。

・光学的遅延帰還によりカオス発振させた半導体レー ザーを励起光源としたTHz-TDSシステムにおいて，名 イポールアンテナを使用した場合, $47.5 \mathrm{GHz}-0.28$ $\mathrm{THz}$ の THz波が発生する。このうち, $180 \mathrm{GHz}$ 以上の 成分が $\mathrm{Fe}_{3} \mathrm{O}_{4}$ によって減衰したことから，レーザーカ オス発生THz波は, 塗膜下腐食検出システムの要素技 術として有望であることがわかった。

謝 辞

本研究の一部は, 福井工業大学の桑島准教授, 情報通 信研究機構の福永氏と水野氏，(株)アドバンテストの山下 氏，西名氏，今村氏の協力の下で実施された。また，本 研究はその全般に亘り電力中央研究所福地上席研究員 より貢献を得た。

\section{参考文献}

1）架空送電設備の鋼材腐食・摩耗現象調査専門委員会 編：電 気学会技術報告 1163 (2009) 。

2) R. F. Anastasi, E. I. Madaras, J. P. Seebo, S. W. Smith, J. K. Lomness, P. E. Hintze, C. C. Kammerer, W. P. Winfree, and R. W. Russell: Nondestructive Characterization for Composite Mater., Aerosp. Eng., Civil Infrastructure, and Homeland Secur. 2007 (San Diego, USA) 65310W.

3) T. Kurabayashi, S. Sakai, and K. Fujino: proc. 35th Int. Conf. Infrared Millimeter and THz Waves (Rome, Italy) p. 1.

4) M. Komatsu, R. Sato, M. Mizuno, K. Fukunaga, and Y. Ohki: Jpn. J. Appl. Phys. 51 (2012) 122405.

5) Y. Oyama, T. Yamagata, H. Kariya, T. Tanabe, and K. Saito: ECS Trans. 50 (2013) 89.

6) 中村悠太, 假屋 英孝, 佐藤 明宏, 田邊 匡生, 西原 克浩, 谷山明, 中嶋か抢り, 前田 健作, 小山裕：材料と環境 63 (2014) 504

7) N. Fuse, T. Fukuchi, T. Takahashi, M. Mizuno, and K. Fukunaga: IEEE Trans. THz Sci. Technol. 2 (2012) 242.

8) N. Fuse, T. Fukuchi, T. Takahashi, M. Mizuno, K. Fukunaga, and T. Okamoto: IEEJ Trans. Fundam. Mater. 132 (2012) 709.

9) 布施則一, 福地 哲生, 水野麻弥, 福永 香: 電気学会論文 誌A 135 (2015) 241.

10) N. Fuse, A. Naganuma, M. Mizuno, K. Fukunaga, T. Fukuchi, and Y. Hori: Corrosion 71 (2015) 1387.

11）布施則一, 福地哲生 : to appear in電気学会論文誌 $\mathrm{A}$ (基礎 · 材料・共通部門誌) 137 (2017) p. 158.

12) I. Duling and D. Zimdars: Nat. Photonics 3 (2009) 630.

13) K. Fukunaga: THz Technology Applied to Cultural Heritage in 
Practice (Springer Japan, 2016) p. 11.

14) P. Debye: Annalen der Physik 348 (1913) 49.

15）荣島 史欣：第60回応用物理学会春季学術講演会（2013） 30a-D1-1.

16）莱島 史欣：光学 $\mathbf{4 3}$ (2014) 223.
17）菜島 史欣：レーザー研究 39 （2011）502.

18) F. Kuwashima: private communication.

19) S. Kharkovsky and R. Zoughi: IEEE Instru. Meas. Mag. 10(2) (2007) 26. 